\title{
Leadership Competences Education for Social Development: a TEC21 Model in the i Semester Experience
}

DOI: $10.46932 / \mathrm{sfjdv2n2-055}$

Received in: january 1st, 2020

Accepted in: March 30th, 2020

\author{
Guillermo Gándara Fierro \\ Tecnológico de Monterrey, México \\ E-mail: guillermo.gandara@tec.mx \\ María Auxiliadora Herrera Martínez \\ Tecnológico de Monterrey, México \\ E-mail: auxi@tec.mx
}

\begin{abstract}
This article shows the results from the experience of the i Semester of the Modality in Leadership for he Social Development during the 2016 August to December semester at the Tecnológico de Monterrey, Campus Monterrey. One of the premises of a semester $i$ is the development of the innovative strategies that facilitate the students the professional competence development by exposing them to challenging activities and the interaction with reality. This experience took place in the San Gilberto community center of the Social Development Secretariat in the state of Nuevo León, México. The approach to the vulnerable community was developed from the framing of social development, a social change plan process whose objective is to promote the population's well being. To this end three challenges were selected whose follow up was leader by two professors, which work in the different roles set up by the new educational models, when guiding the work of seven students. Through the i semester experience the possibility of helping the community's transformations was explored. Continuity to this coexisting project presented is expected, as an idea alternative to restore the community, which was fracture due to the conditions of insecurity in which it is currently immersed.
\end{abstract}

Key words: Social development, semester i, social leadership, social innovation, community centers.

\section{INTRODUCTION}

Following the 2012 petition made by the Instituto Tecnológico y de Estudios Superiores de Monterrey's Directive Council to continue the academic quality strengthening in face of 21 st century challenges, design work of a new educational model was done in this institution. The objective of this new educational model named Tec 21, is to "bring an integral formation and improve the students competitiveness in their professional field by increasing the skills of coming generations in the development of the required competences that will allow them to become into leaders that face the challenges and opportunities of the $21^{\text {st }}$ century" (ITESM, Modelotec21, 2016).

The platform of this educational model hinges on four components, which guide and conform the student's leadership: 
1. Challenges based learning,

2. Flexibility in the how, when and where learning occurs,

3. A memorable university life,

4. Inspiring professors.

Regarding the previous framing, the general objective of this article is to show and analyze the results of one of the programs that forms this new educational model: the semester i experience in the Social ${ }^{1}$ Development Leadership Modality, deployed throughout the August-December 2016 semester at the Tecnológico de Monterrey, Campus Monterrey. The reflections regarding the learning of this educational experience are also presented.

The following is the theoretical framework, which functions as a general core to the design of an i semester under the scheme of competences base education and the specific framing of social development. In the third chapter the particular details of this educational project are presented: competences, challenges, learning modules, valuation schemes and forming partner. In the fourth chapter the results are shown, which are discuss in the fifth chapter. Finally we close the document with a set of general conclusions.

\section{THEORETICAL FRAMEWORK}

What are the basic elements needed to describe a competence? There are several valid declarations regarding the meaning of a competence, however, at the Tecnológico de Monterrey the declarations of competences makes reference to a concrete and observable actions (verb) for which evidence can be made as a form of performance. This action must be focused on a conceptual construct (object) or concrete situation, under which the action is performed. Likewise it establishes a condition of quality or reference criteria that will be used to express the quality of the achieve goal. (ITESM Modelotec21, 2016).

In this space, a competence is the conscious integration of knowledge, skills, attitudes and values that allows facing successfully both structure and uncertain situations, and that implies higher order mental processes. Therefore, competences integrate both the knowledge and procedures related to the discipline, such as the attitudes and values that allow performance as participative professionals committed to society. According to statements from the Tecnológico de Monterrey, challenges base learning exposes the student to real problems so that transformational leadership competences are developed.

\footnotetext{
${ }^{1}{ }^{1}$ The i Semester is a program part of theTec21 Educational Model, where bachelors student from the Tec de Monterrey strengthed and develop their competences through lived learning experiences. (http://semestrei.tec.mx/semestre-i ).
} 
The flexibility of the Model TEC21 offers the student more options regarding the what, how, when and where of his professional learning process through flexibility in the studies plan and the learning experiences. Meanwhile professors are recognized as academics, leaders in their discipline and as a guide that enhances student's development. Finally, the students live during their formation period in a community of global and multicultural learning that fosters the development of different competences.

On Model TEC21 the challenges based learning exposes the student to real problem with the goal of competences development, which is result through the support of forming partners who are committed to the development of the student's competences. The thematic contents within semester i, are organized by way of modules that are designed and programed according to the graduating competences that are sought and to the characteristics of the challenge (ITESM, Semester i, 2017).

Therefore, in relation to the previously exposed (Caffarel et al., 2016) emphasize that the Tecnológico de Monterrey has distinguished itself through continuous evolution, which is the reason why now looks for the development of innovative strategies, that facilitate the professional competences development of students by exposing them to challenging activities and interaction with reality. They declare that "such competences have been formed into the elements which move professional development [since], a student form under this focus, is developed with an education and an integrated and holistic vision that come from learning scenarios taken from a complexity of situations that the student interacts with. (Page 960)".

The educational project here presented was developed in the context of the Social Leadership Modality program (MLDS), which after more than 15 years of experience has sought to strengthen professional competences in the student for the recognition of opportunities and the generation of solutions through the development of social impact projects (ITESM, 2016).

The frame of reference for the design and realization of this intervention is Social Development. According to Midgely (1999) social development is a planned process of social change, design to promote the well being of the population as a union with the dynamic of economic development process. This social well being exists when families, communities and societies experience a high level of quality of life. In other words when achieved: a satisfactory resolution of social problems (for example family disintegration, unemployment, crime and violence); a satisfaction of social needs (such as nutrition, drinking water, personal safety, social security and education, to mention a few); and develop the opportunities for people to realize their full potential.

Therefore the central axis of our social development project is the Logical Framework Focus. One of the most internationally used methodologies, recognized for its validity and quality in the planning and negotiation of community interventions (García y Justicia, 2012). The Logical Framework Focus (EML) 
it's an instrument of logical analysis and of structured thought in the planning of social projects. The departing point is the deep analysis of the social problems and needs developed in stage 1 named Research and Diagnostic; next, in stage 2 Design and Formulation, the objectives activities, resources and performance indicators are derived; afterwards we make way for the intervention in stage 3 Implementation and Follow Up; and finally, once the project is finished, we proceed to evaluate results and impacts in stage 4 titled Evaluation. Additionally this is a method of consensus driven participatory planning (Ortegón et al., 2005).

\section{DESIGN OF THE SEMESTER I IN THE LEADERSHIP FOR SOCIAL DEVELOPMENT MODALITY}

In this section the design elements of the Semester $\mathrm{i}$ in the Leadership for the Social Development Modality are described: competences, challenges, learning modules, evaluation policies and educational partner.

\subsection{COMPETENCES}

As described in the introduction, an i semester seeks to influence the development or consolidation of certain competences in students, at the same time, given the MLDS' particular nature, treating problems or social development limitations is sought. Therefore the general objective of this social problem was targeted to contribute to the integral human development of the San Gilberto community.

In accordance to Caffarel et al. (2016) the definition of competences originates in a clear exit profile of the alumnus characterized by the MLDS, as shown in Table 1. The competences to be developed are: i) diagnose the organization or community in accordance to specific conditions, ii) design and manage social projects that generate innovative sustainable and transferable solutions, contributing to the improvement of people's conditions and quality of life; and iii) exercise leadership abilities for social development and visualize this role's impact in the framing of social development policies. Likewise, each of the principal competences includes four sub competences.

Table 1. Competences and sub competences of the MLDS i Semester

\begin{tabular}{|l|l|l|}
\hline $\begin{array}{l}\text { 1. Diagnose the organization or } \\
\text { community in accordance to } \\
\text { specific conditions. }\end{array}$ & $\begin{array}{l}\text { 2. Design and manage social } \\
\text { projects that generate innovative } \\
\text { sustainable and transferable } \\
\text { solutions, contributing to the } \\
\text { improvement of people's } \\
\text { conditions and quality of life }\end{array}$ & $\begin{array}{l}\text { 3. Exercise leadership abilities for } \\
\text { social development and visualize } \\
\text { this role's impact in the framing of } \\
\text { social development policies }\end{array}$ \\
\hline $\begin{array}{l}\text { 1.1 Describe the social reality } \\
\text { that approximates, with the } \\
\text { sense of empathy and }\end{array}$ & $\begin{array}{l}\text { 2.1 Recognize the concept and } \\
\text { practice of social innovation, the } \\
\text { sustainability principles and } \\
\text { professional ethics }\end{array}$ & $\begin{array}{l}\text { 3.1 Demonstrate the leadership } \\
\text { assuming an agent for change role } \\
\text { with future vision, promoting an }\end{array}$ \\
\hline
\end{tabular}




\begin{tabular}{|l|l|l|}
\hline $\begin{array}{l}\text { considering the ethical and civic } \\
\text { implications }\end{array}$ & $\begin{array}{l}\text { ethical dialog to strengthen the } \\
\text { civic capabilities }\end{array}$ \\
\hline $\begin{array}{l}\text { 1.2 Identify and analyze the } \\
\text { environment's needs to } \\
\text { recognize opportunities and } \\
\text { visualize possible solutions to } \\
\text { people's and environmentalism } \\
\text { needs }\end{array}$ & $\begin{array}{l}\text { 2.2 Generate and evaluate } \\
\text { solution proposal with involve } \\
\text { stakeholders, using } \\
\text { methodologies that promote } \\
\text { participation and consensus }\end{array}$ & $\begin{array}{l}\text { 3.2 Organize multidisciplinary } \\
\text { teams talent and heterogeneous } \\
\text { groups oriented to improve quality } \\
\text { of life }\end{array}$ \\
\hline $\begin{array}{l}\text { 1.3 Classify and evaluate social } \\
\text { development needs, trough the } \\
\text { use of situational diagnostic } \\
\text { methods and tools }\end{array}$ & $\begin{array}{l}\text { 2.3 Proposes a social project with } \\
\text { all the necessary formal elements, } \\
\text { and considering the efficient use } \\
\text { of resources }\end{array}$ & $\begin{array}{l}\text { 3.3 Recognize national and } \\
\text { policies and act with responsibility } \\
\text { towards different instances that } \\
\text { have an impact in people's quality } \\
\text { of life }\end{array}$ \\
\hline $\begin{array}{l}\text { 1.4 Define integral solution } \\
\text { alternatives according to the } \\
\text { diagnostic }\end{array}$ & $\begin{array}{l}\text { 2.4 Manage implementation of } \\
\text { the project integrating } \\
\text { mechanisms of evaluation and } \\
\text { follow up }\end{array}$ & $\begin{array}{l}\text { 3.4 Consciously value the social } \\
\text { reality in which it participates }\end{array}$ \\
\hline
\end{tabular}

\subsection{CHALLENGES}

In this context and following the challenge's based learning Model (ITESM, Modelotec21, 2016), the challenges establishment is fundament in a recognition of the social needs in the field, in a reflexion and internal valuation, along side the forming partner's requirements.

The MLDS i Semester was structured in the following three challenges:

- Challenge 1. Diagnostic and characterization of the situation under study. The objective of this challenge was to realize a diagnostic of the situation lived in the San Gilberto community, as the functioning of the San Gilberto Community Center, through the use of quantitative and qualitative tools for the recollection and analysis of information.

- Challenge 2. Design of the Social Project. The second challenge consisted in proposing solution alternatives. The possible solution alternatives were submitted to an evaluation process under quantitative and qualitative criteria. The project's design was defined using a projects planning matrix.

- Challenge 3. Social Project's Implementation. Finally, the third challenge consisted in executing the project's activities according to the follow up plan the implementation products and results were described. Additionally a proposal for the project's evaluation was realized and recommendations for the project's continuity were made.

Therefore, the student participates actively and as part of a team, in a community center and the attended community, developing a diagnostic and characterization of the situation under study, the design of a social project and his corresponding implementation. 


\subsection{LEARNING MODULES}

Once the three challenges were selected the learning modules were designed. This process implied a profound dialogue among the professors involved in the project, about the respective specialization areas as well as an ample reflexion in regards to the contribution of each discipline to the success of the three challenges. Likewise, it was very important to define the best moment for each subject's inclusion, contemplating the knowledge needed by the students to solve each challenge and responding to the following question, what does the student need to learn to solve the challenge and develop the established sub competences?

This learning modules design implied that each professor had to let go their own particular disciplinary vision, facing instead the construction of a holistic vision that required the success of the declared sub competences in each challenge. With this in mind, the professors team studied the curricula of each subject involved in the semester i: Applied Ethics, Citizenship and Democracy, Organizational Behavior, Human Talent Development, Evaluation in Project Management, as well as the topics linked to social development (The social Leader and his context, and Methodologies for the design of social projects)

After words the necessary topics were organized caring for the academic rigor by avoiding content duplicity. That way, the following ten learning modules were generated for which each individual instruction involved the participation of between two and six professors:

1. Leadership and social development

2. Systemic thought and participatory processes

3. Situational diagnostic

4. Citizens controversies and ethical dilemmas in the profession

5. Project and social innovation alternatives

6. Evaluation and projects selection

7. Design and projects management

8. Citizen's principles and ethical imperatives for the profession

9. Critical thought for the personal an social conscience

10. Prospective for social leadership

The structure's construction of semester i was developed supported on a paper based chronogram, where each day and hour was represented alongside the seventeen weeks of the semester (Caffarel et al., 2016). There, using colored "Post-it" notes the challenges, learning modules, presentations, plenary sessions, coaching spaces and evaluation spaces, among others were detailed, as shown in Figure 1 
Figure 1. Structure of the MLDS Semester i

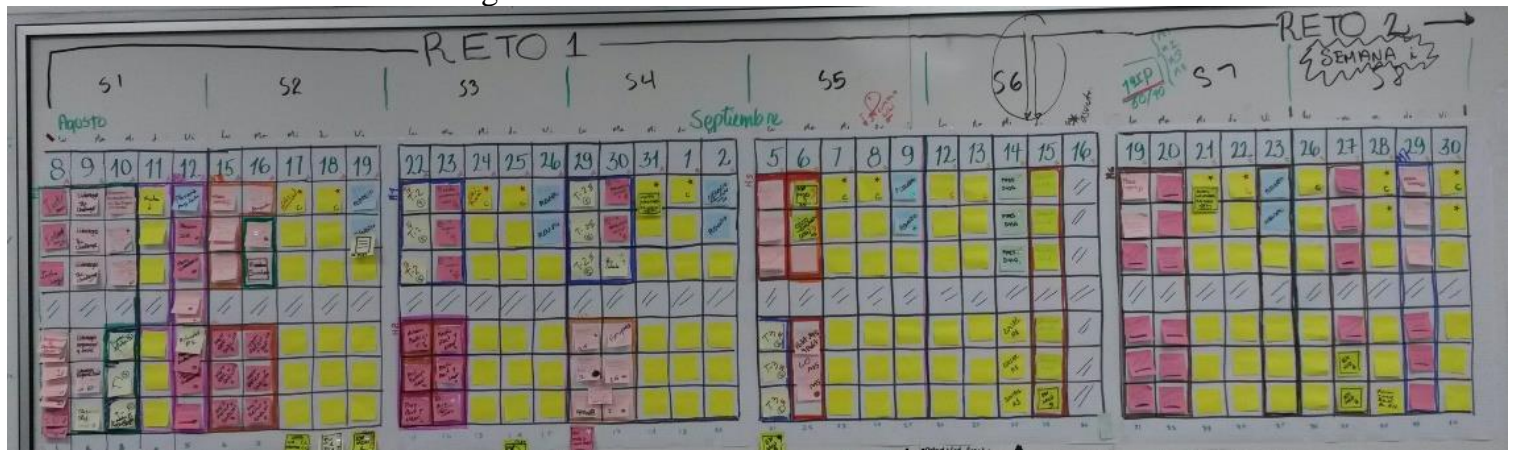

(Source: Caffarel et al., 2016)

It is relevant to emphasize that when taking each module the student gradually acquires the knowledge and skills necessary to successfully credit the proper sub competences for each one of them, focusing on developing the three competences declared in this Semester i with a high level of mastery. This is why this design face is considered as the heart of the semester i. To clarify this last point we will move to the evaluation face.

\subsection{EVALUATION POLICIES}

Evidences and instruments for the multidisciplinary Semester i evaluation policies were developed. On one hand the follow up of the competence and sub competences formation involved the definition of four mastery levels contemplating both disciplinary as well as transversal elements.

Thus, the competences and sub competences evaluation form is an instrument that details for levels of mastery for each sub competences taking as reference the different levels of the $\mathrm{Jedi}^{2}$ force (initiate, padawan, knight and Jedi). This decision was taken seeking proximity with the students, but in this process care to include in each mastery level the evaluation instrument that will back each disciplinary and transversal evidence required from the students.

On the other hand by being still in a process of institutional transition that ranges from an evaluation of curricular subject to a competences based evaluation, the integration of the grade was reported per subject. In general terms this evaluation scheme integrates $60 \%$ of the grade to challenges development and competences formation, and $40 \%$ to the Modules development. The incorporation of this last percentage in each subject is in function of the contents of the modules linked to each one.

\subsection{EDUCATIONAL PARTNER}

The development of the Semester I was done hand in hand with the Ministry of Social

\footnotetext{
2 The different force level within the Jedi require harsh trainning levels if sought to be used for good. Taken from:
} http://www.starwars.com/ 
Development of the Government of the State of Nuevo Leon (SDSGNL), who assumed the role of Educational Partner. Through its network of 41 community centers, the SDSGNL seeks to face the marginalization and rejection of the population residing in poverty polygons. The San Gilberto Communication Center (CCSG) is part of this network.

The CCSG was founded in 2007 as a learning place with the purpose of socially developing knowledge and values, and where its participants develop skills and attitudes through their own experiences. Today, the CCSG mission is to offer classes and workshops aimed at children, youth and adults for this development of skills and capabilities, along with the possible commercialization of its products (Gobierno del Estado de Nuevo Leon, 2015). The Center is a government entity interested in having its participants deploy the skills that serve them both for their personal growth as well as an earning opportunity, hence covering latent needs of the neighborhood, such as safety matters and land appropriation in a beneficial manner for the neighbors.

In the San Gilberto neighborhood, being a settlement planned for local people displaced due to natural disasters, a space for social reinsertion is needed that attracts different groups of people, independently of each person's age and job (Melendez et al., 2016). For further detail regarding the CCSG activity, look at https://es-la.facebook.com/CC.SANGILBERTO/

\section{RESULTS OF THE MDLS SEMESTER I}

The following are the principal results of each of the taken challenges during the 2016 August-December semester, beginning with a description of the study zone.

\subsection{DIAGNOSTIC AND CHARACTERIZATION OF THE STUDY ZONE}

The project begins with a walk around the study zone (Figure 2) that allows the students have a first approach to the community. The community where this educational experience is developed is the San Gilberto neighborhood located on the edges of the Metropolitan Area of Monterrey (ZMM) in the Santa Catarina County. The San Gilberto neighborhood is named after the Gilberto hurricane, which severely affected the whole ZMM on September 17th, 1988 causing hundreds of deaths, missing persons and thousands of displaced people (Cabrera et al., 2013). Several affected people were relocated in this area. Thus, this neighborhood was created, which soon was turned into an important focal point for urban growth in the city.

According to INEGI (2015), the neighborhood has 83 blocks, out of which $96 \%$ are paved, $83 \%$ have sidewalks, $78 \%$ have trees and 79\% has public lighting. By 2010, out of the 2,927 private homes, $89 \%$ had tiled floors, tubed water and drainage, electric power and W.C. On the other hand, $5 \%$ of the 
private homes were uninhabited. The neighborhood population in 2010 was conformed of 13,516 inhabitants, with the following distribution: $28 \%$ between $0-14$ years old, 31\% between 15-29 years old, $35 \%$ between $30-59$ years old, and 6\% with 60 years of age or more. A total of 377 people had some form of disability.

Beyond statistics, it is necessary to consider the location of the neighborhood and what this represents for its social insertion within the ZMM. By 2016 the San Gilberto neighborhood was the second to last neighborhood located to the northeast of Santa Catarina, before the paved areas end and the Sierra de las Mitras Reserve begins (Melendez et al., 2016). It is a marginalized zone not only on geographical terms but along several dimensions of human development. During the first weeks the effects of the principal problem areas were perceived: lack of maintenance in public areas (parks, dirty and unkempt fields), multi dimensional poverty (lack of health services, education and social welfare), a feeling of insecurity and pollution (garbage and stale water).

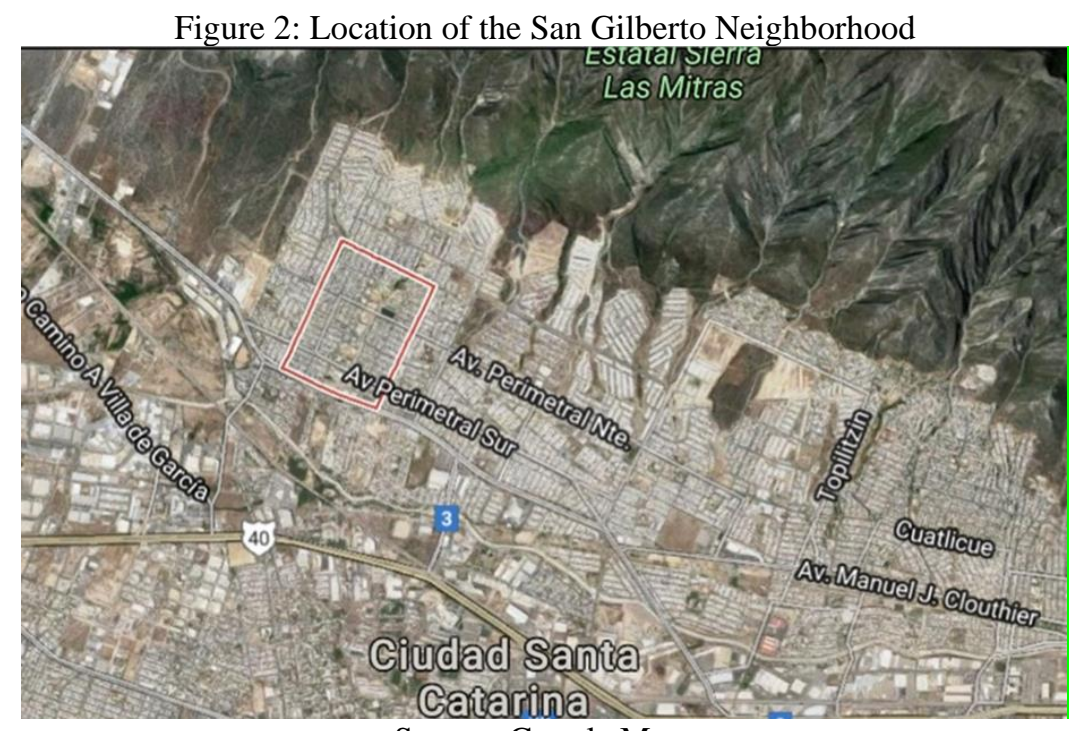

Source: Google Maps

Economically, according to INEGI (2014) San Gilberto has 230 businesses among whom the core economic activities are small-scale retail (mom and pop shops) of daily items, food, drinks, ice and tobacco; food and drinks preparation services; and other services such as maintenance and repair (automobiles, electronic equipment, etc.), personal services (salons, laundry, parking, etc.), civil associations and non-government organizations.

One of the first results of the diagnostic is the participant's analysis, identifying both beneficiaries and stakeholders. Users of the CCSG, their workshop employees and administrative personnel, along with the students of the Semester I were the direct beneficiaries. The CSG, government, associations, family members of users and private institutions are the indirect beneficiaries. Among found the grieved or 


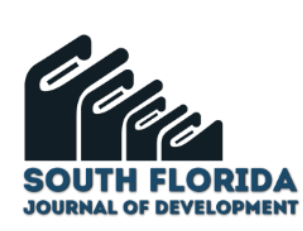

opponents were: public servants, drug cartels and internal CCSG leaders. The stakeholders were identified according to their nature; public sector, private sector and civil society organizations. Among the first we find the Social Development Secretariat and the Santa Catarina Municipal Government; within the private sector we mainly find donors of material goods (Allen, Bocados, HEB-Alimentos); several nongovernment organizations operate in the area, among them, Alianza Educativa, Fundación Santos, de la Garza Hevia and Caritas.

The context analysis includes both the expressed social problems mapping in the problems tree (Figure 3), as the SWOT analysis.

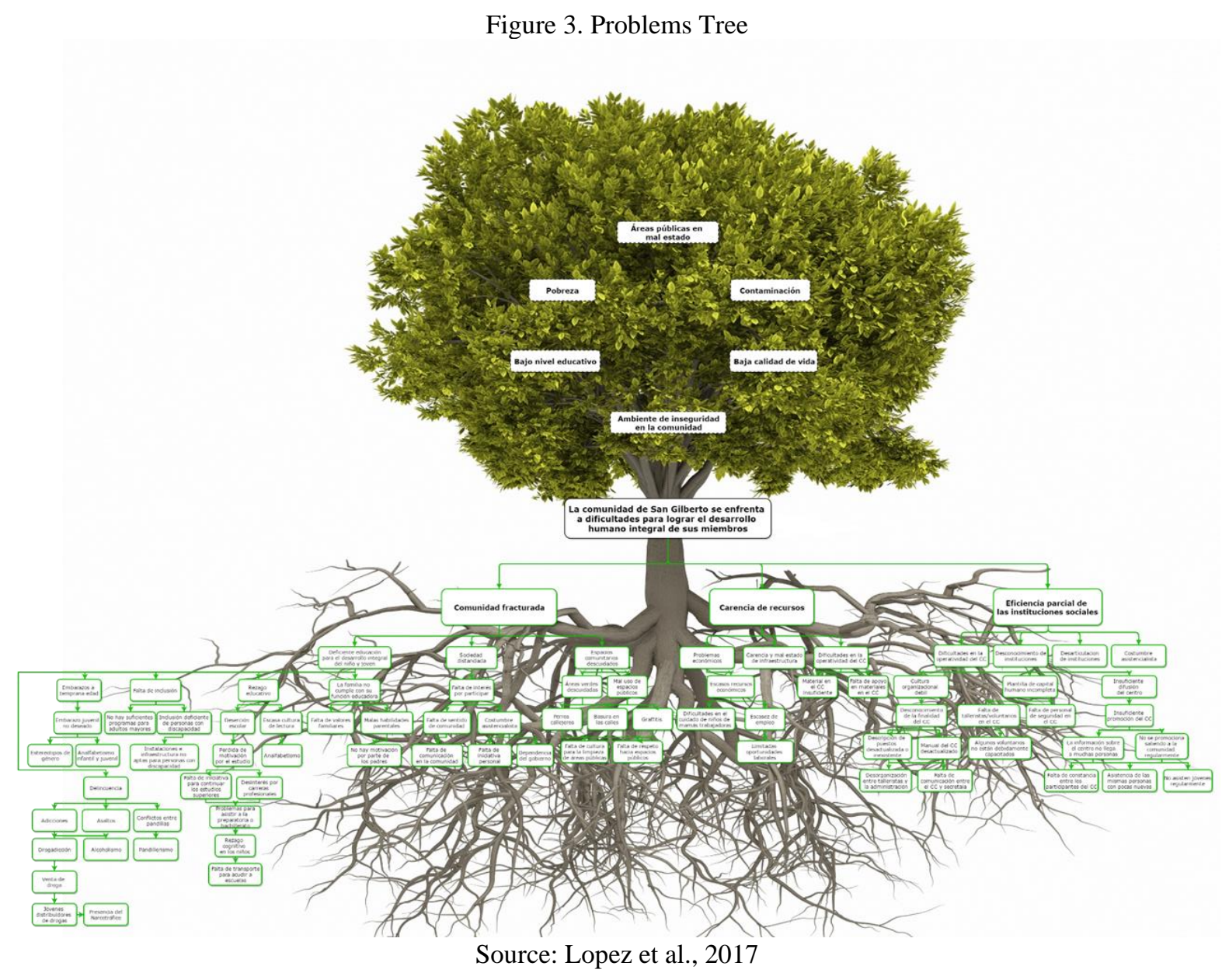

As one can observe in the trunk, the central problem that the San Gilberto community faces is difficulties for the integral human development of its members. With medium and long term consequences such as poverty and low quality of life, among others. The roots of the tree refer to the main causes of the problem and their respective causes. Hence, the first level causes presented are grouped in three dimensions: fractured community, lack of resources and deficient management of the community center. 
In regards to the internal analysis, among the strengths we have: a high number of active organizations, the CCSG have 73 workshops and workshop workers trained in their fields teach these. Meanwhile as weaknesses we find: the deficient diffusion of activities done in the center, out of date process manuals and the lack of knowledge regarding basic concepts of organizational culture.

In regards to the external analysis the main threats are: the community's conformism, youth involved in criminal organizations, drug trafficking and drug peddling. But also opportunities are appreciated such as: the social responsibility of companies, sport activities for the youth and alliances with other institutions.

The first challenge finalizes with the proposal of alternative solutions. From the tree of objectives and the socialization of the different alternatives with CCSG personnel, mentors and tutors, four possible social projects were defined to face the identified problems: huateque, punto recompensa, empretalleres and young leaders (líderes jóvenes).

The first one consists of a periodical cultural, sport, commercial, entertainment and musical event in the community, which affronts the problems of youth involvement with gangs and the fractured community. The second one seeks the promotion of the CCSG by way of incentives. The third consists in giving workshops focused on work related skills learning within the CCSG according to the requirements of local businesses interested in hiring people from the CSG. The fourth consists in forming a group of young people from the CSG with leadership skills and civic values so that they apply these towards the rest of the community and organize events such as the huateque. This alternative faces the gangs, drug addiction, youth pregnancies and school disinterest problems.

\subsection{DESIGN OF THE SOCIAL PROJECT}

The definition of solution alternatives was a planned process starting from the objectives tree and within the frame of the Social Innovation Sojourns, following by a deep analysis and dialogical both with the CCSG Coordinator, a well as with the SDSGNL mentor and tutors. Having as a result a proposal of solutions with the desired innovation, sustainability and scalability characteristics.

After a qualitative and quantitative evaluation of the solution alternatives in the second challenge Huateque and Young Leaders (Lideres Jovenes) were selected to integrate on social innovation project. A project was designed following the formal elements from the EML: goal, purpose and 7 components, 19 follow up indicators with their verification means, and 99 activities with their material, human and financial resources requirements, besides their programming in a chronogram. The goal of this project has been expressed in the objectives tree, which implies the partial realization of the long-term impact, which is: promote the integral human development of CSG members. The project has the purpose of restoring 
the fractured community and the social propinquity through the creation of a convivial event every three months in the CSG, organized by the Young Leaders Committee (CLJ).

\section{4 PROJECT IMPLEMENTATION}

The first edition of the Huateque happened on November $13^{\text {th }}, 2016$ was inaugurated by SDSGNL authorities from the Community Centers area, with a quorum of 320 people out of which $18 \%$ were girls, $21 \%$ boys, $26 \%$ youth, $32 \%$ adults and $3 \%$ elderly people. During the event diverse activities were realized oriented at the different users and CCSG non-user publics: sports, ludic, gastronomical, cultural, entertainment and play.

As part of the challenge, four reports were created, which were transferred to the Center Promoter and delivered to the SDSGNL: general project report, the Huateque manual, young leaders' manual and results of the administered surveys. The Huateque manual shows the way in which the Huateque event should be realized. The young leaders' manual shows how the group tasked with organizing the Huateque should be formed. There were two types of surveys during Huateque: sports and general event, the surveys were administered within the Huateque, A third result of this challenge was the seminar realized at the CONALEP, attended by close to 50 young people from the San Gilberto neighborhood, with whom the project was shared and to whom a seminar with leadership exercises and talks were given. Greater detailed results can be observed in Lopez et al. (2017)

\section{RESULTS DISCUSSION}

Given the Semester I characteristics, during the first challenge it was necessary to begin the process of temporal working groups formation. Robins \& Judge (2013) explain that when temporal working teams form, that is, for a specific project, and therefore with beginning and end dates, these usually move through "a predictable sequence during their evolution" (pp. 274) as it's shown on Figure 4. Likewise, they warn that this transit happens at different rhythms for each group and in each situation.

They also observe that the groups begin with a positive social focus, as well as with a clarity of purpose and strategies, they quickly reach a high performance and improve over time, reaching the "performance" phase with greater speed. Afterwards they prepare to enter the suspension or task ending phase, "where the group closes down their activities and prepares for dissolution" (pp. 275). 
Figure 4. Effective groups formation

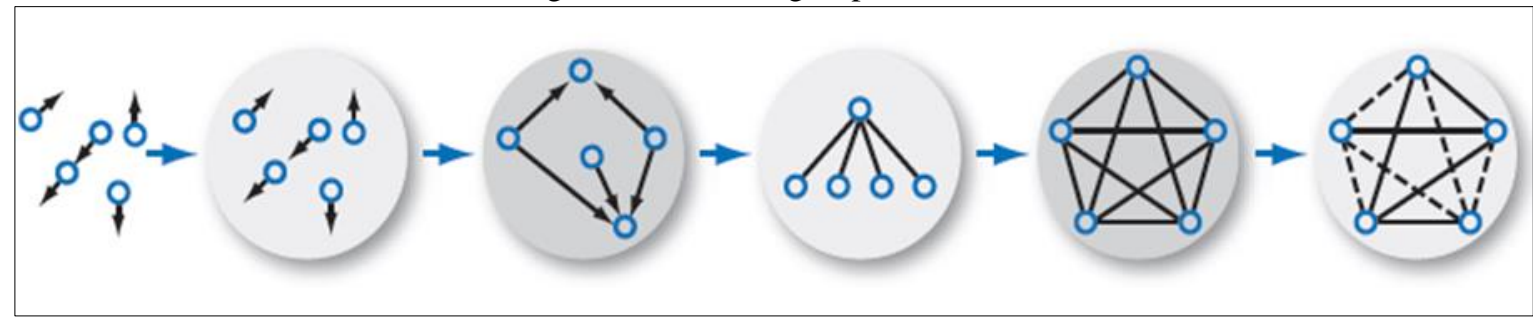

Source: Robins \& Judge (2013)

At the beginning of the semester I, there were two teams of students working independently in the SCSG. Each team elaborated the first two partial reports independently. However, from the third partial report onwards the need of making a joint diagnostic results front was needed to face the presentation of the final report of the first challenge to the SDSGNL. As mentioned by Robins \& Judge (2013), the formation phase of this new task force was difficult, specially given the uncertainty caused by the new team's structure and leadership. The storm phase was characterized by internal conflicts within it, but after the tasks and roles analysis, the group's structure was consolidated becoming quite functional. During the performance phase, more robust results than those from when they were two separate teams were reached, and from then onwards, they worked with a more complex and global, multidisciplinary vision.

Meanwhile, the elaboration of the problems tree was developed through a consensus process using nominal technique. From the problems analysis, where each participant in the group stated the detected problems by primary and secondary sources, a catalogue was created for a future causal structuring by problem's families.

A critical point was presented during the evaluation and alternatives selection process. For the evaluation, there was a member who was very close to one of the alternatives with the least amount of points. After a long consensus process, the member accepted the group's result. At the same time in which they were converted into the integration guide for the Young Leaders Committee (Comité de Líderes Jóvenes). Since this is a temporal team, and as mentioned by Robins \& Judge (2013), the team slowly prepared for its disintegration and to leave the continuation of the project flow into the new Committee in an autonomous fashion (see Figure 4).

During the third challenge, and given the pressure of the delivery times, some of the students had to take a much more proactive leadership role in order to reorganize the team's effort, and push the project through. One of the most important challenges during the implementation of the accorded solution, as the integration of a committee with the same young people of the San Gilberto community, which would give the possibility for the initiative to be replicated in the future, once the Tec de Monterrey students retired from the San Gilberto Community Center. The first call for the young members of this community to 
integrate the so called youth committee didn't have a good response, so it became necessary to design a strategy to make the integration of such committee a success. The follow-up system allowed conducting the change of strategy in regards to the integration of the Youth's Committee. Alternatives against the lack of response for the first call were sought. Finally, the solution consisted in an alliance with the CONALEP so that through their social works in the CCSG the students from the San Gilberto neighborhood would confirm the Youth Leaders group for the Huateque coordination.

Another obstacle for the success of the objectives was to face the lack of economic resources towards the proposed solution implementation. There was confusion in regards to the available resources needed to begin, so the students had to generate alternative plans to get resources. With the goal of avoiding the end of the project because of this situation the following alternatives were followed: the raffle of a donated article and communicating with stakeholders that could help with the success of the project (both public and private institutions).

In respect to the organization of the Community Center, it is necessary to explain that it counted with an incomplete organizational structure. This fact made the practical implementation of the found solution difficult, since as Robins \& Judge (2013) state, the clarity of an internal structure within an organization contributes to the explanation and prediction of individual and group factors, as well as the achievement of the organizational objectives. In consequence, the absence of clear power relations and of unity in command and decision making authority, became an obstacle to the achievement of the objectives posed by the students. For example, before the end of the project the community center's manager and mentor changed, so the students had the opportunity of experiencing clearly and first hand, what the literature states as priority for the success of organizational objectives.

\section{CONCLUSIONS}

The Semester i project allowed contributing to the empowerment of the CSG through the realization of a social project based in solving three challenges: situational diagnostic, project design and project implementation. For the development of the challenges the students prepared by taking ten modules of academic contents. Facing the central problem of a deficient integral human development, the project had the purpose of restoring the fractured community by getting people closer through the realization of a social gathering named Huateque.

There were learnings for each phase of the process. It is important to signal the importance of having a complete organizational structure from the field exploratory phase during the diagnostic, all the way to the transfer of results at the end of the implementation. 
The solution's alternatives definition had as a result a solutions proposal with the desired innovation, sustainability and scalability characteristics. Meanwhile the follow-up system allowed for a shift of strategy in regards to the integration of the Youth's Leaders Committee.

The leadership skills developed by the students during the project's implementation are to be mentioned, when contacting public and private stakeholders for the realization of the Huateque and the integration of the Youth's Leaders Committee.

For the results to be maintained in the long term, it is important to successfully make the local people within the community to be self sufficient, that is, to have the capacity to assimilate the learnings and benefits that these types of projects bring and becoming themselves capable of giving continuity to the initiative.

The follow-up of the project is conditioned not only to the appropriation on behalf of the community and the leadership of the Youth's Leaders Committee, but also on the indispensable support and involvement of the forming partners, through a solid organizational structure that allows and facilitates the recommended planning.

Following two years after the implementation of the Huateque, there hasn't been continuity of the event in the terms in which it was designed, however the same has been replicated by other government instances in other parts of the city. Also, improvements in the public space of the area where Huateque was made, have been observed.

\section{ACNOWLEDGEMENTS}

We thank Lauren María López, José Emmanuel Morales, Cristina Robles Estrada, Sofía Quiroga Vázquez, Jorge Luis Salazar García, Mariana Cárdenas Tamez., Oscar de Hoyos Jaidar, Eliam López, Sara María Ling and the administrative team of the San Gilberto Community Center, for their effort, passion and commitment to the realization of this project. 


\section{REFERENCES}

Cabrera, E., González, H., \& Garza, A. (2013). Excélsior en la Historia: Gilberto, el huracán del siglo. Recuperado en septiembre de 2016 de Excélsior: http://www.excelsior.com.mx/nacional/2013/09/17/918932

Caffarel, G.; Gándara, G.; Herrera, M.A.; Reyes, E.; Treviño, A. y Rivas, J. 2016. ciie.itesm.mx/es/memorias/. Obtenido de ciie.itesm.mx/es/memorias/: https://drive.google.com/file/d/0B6XV2TpdFh5yR0drTDhKRFZZZWc/view

García y Justicia, Javier. 2012. Elaboración de Proyectos de Desarrollo para Organizaciones de la Sociedad Civil. Monterrey: Gobierno del Estado de Nuevo León.

Gobierno del Estado de Nuevo León. (14 de enero de 2015). Cursos y talleres en los Centros Comunitarios. Recuperado en septiembre de 2016 del sitio web del GENL: http://www.nl.gob.mx/servicios/cursos-y-talleres-en-los-centros-comunitarios

INEGI. (2014). Directorio Estadístico Nacional de Unidades Económicas. Recuperado en septiembre de 2016 de INEGI: http://www3.inegi.org.mx/sistemas/mapa/denue3d/default.aspx

INEGI. (2015). Inventario Nacional de viviendas 2015. Recuperado en septiembre de 2016 de INEGI:http://www.beta.inegi.org.mx/app/mapa/inv/default.aspx

ITESM. 2016. Modalidad de Liderazgo para el Desarrollo Social. Documento de trabajo.

ITESM. 2016. Modelotec21. Obtenido de Modelotec21 Web site: https://sitiosmiespacio.itesm.mx/sites/tec21/profesores/que-es-el-modelo.html

ITESM. 2017. Semestre $i$. Obtenido de semestrei.tec.mx/semestre-i Web site: http://semestrei.tec.mx/semestre-i

Meléndez, F.; González, M.; Collado, J.C.; Guerra, M. y Vigil, M. 2016. "Revitalizando la convivencia comunitaria: comunicación estratégica en el Centro Comunitario San Gilberto". Curso Gestión de Proyectos Públicos y Sociales”. Tecnológico de Monterrey.

Midgely, James. 1999. "1. A Definition of Social Development" en Social Development, the developmental perspective in social welfare. SAGE Publications Ltd, London. Pp. 12-36.

López, L.M.; Robles, C.; Quiroga, S.; Salazar, J.L.; Cárdenas, M.; Morales, J.E.; de Hoyos, O.; Herrera, M.A. y Gándara, G. 2017. "Reporte final del reto 3: Diseño del Proyecto Social Centro Comunitario San Gilberto”. Semestre i Modalidad de Liderazgo para el Desarrollo Social. Tecnológico de Monterrey.

Ortegón, Edgar; Pacheco, Juan Francisco y Prieto, Adriana. 2005. Metodología del marco lógico para la planificación, el seguimiento y la evaluación de proyectos y programas. CEPAL- Instituto Latinoamericano y del Caribe de Planificación Económica y Social (ILPES).

Robins, \& Judge (2013). Comportamiento Organizacional. Mexico: Pearson. 